\title{
Disability and Children as Begging Guides: For how Long Shall Children be Used as Begging Guides by Visually Impaired Persons in Africa?
}

\author{
Samuel Chukwudi Agunyai and Victor Ojakorotu
}

Department of Political Studies and International Relations, North-West University, Mafikeng, South Africa

\begin{abstract}
This study examines the effect of using children as begging guides by people with sensory disabilities in Africa. It argues that in some African countries, visually impaired persons, especially parents and relatives, have devised the strategy of abusing their children or someone very close to them as begging guides for financial gain. While this strategy has remained a recurrent problem with severe social, economic, political, and legal implications, scientific research on addressing these implications is scarce. Given this, the article examines the rationale for using children as begging guides, its effects on the children and visually impaired parents, and mitigation strategies against abuse of children as begging guides in Africa. The qualitative research design based on key informant interviews (KIls) complemented social exclusion and childhood theoretical underpinnings of the study. Results from (KIls) showed that poverty, religion, cultural beliefs, financial profiteering, poor governance, breakdown in policy implementation against begging are among the rationale why children are abused and used as begging guides. The results also showed that these children experience low academic performance in school, harassment, psychological trauma, health complications from laborious trekking. At the same time, their visually impaired parents suffer from regrets and guilt of not being able to provide good parental care to their children. It concludes that good rehabilitation, vocational programmes, and prompt government supports for people with sensory disabilities would lessen the abuse and use of children as begging guides in Africa.
\end{abstract}

Keywords: Begging, children, disability, guides, visually impaired persons, sensory disabilities.

\section{INTRODUCTION}

Following the usage of children who are supposed to be in school as begging guides in Africa, disability and its awful underlying conditions among victims have taken on a pitiful dimension [1]. While some research $[2,3]$ have looked into how to improve the dreadful conditions of people with disabilities, the plight of ablebodied children or young caregivers who are employed as begging guides by people with disabilities is frequently overlooked. As a result, while disability is a problem that requires multipronged intervention, its proclivity for turning into a more serious problem, particularly in terms of depriving children of their rights, especially, right to education, also warrants attention. This is critical because using children as begging guides restricts their right to education and, in the long term, undermines the SDGs goal four (education for all). Education is supposed to be for all, including children, able and disabled persons, but the reverse is the case for children used as begging guides. In fact, International Labour Organization sees it as child labour because being used as begging guides is physically and psychologically damaging ${ }^{1}$.

*Address correspondence to this author at the Department of Political Studies and International Relations, North-West University, Mafikeng, South Africa; Tel: +27731399937; E-mail: agunyais@oauife.edu.ng

${ }^{1}$ ILO defines child begging involving children of age 15-17 years as child labour, especially, if their work is physically and psychologically damaging (ILO, 2017).
Available data shows that approximately 215 million children, the majority of whom are in Africa, are child labourers, including those being used as begging guides [4]. It violates the fundamental human rights of children, especially their rights to education, good health, physical and mental development [5]. It impedes the time spent in school and academic performance [6]. This is partly caused by the increasing rate of visually impaired persons in Africa. For instance, according to [7], the rate of visually impaired persons in Africa is estimated to be greater than $80 \%$ in eastern, western, and central Sub-Saharan Africa, compared to $10 \%$ rate in other continents such as Australasia, Western Europe, Asia-Pacific, and North America ${ }^{2}$. It is imperative to note the prevalence of this problem and the absence of government intervention to protect victims of sensory disability had made many of them seek self-help to salvage themselves from inherent problems of disability.

Currently, parts of the self-help adopted by some of them are the use of their children or young relatives as begging guides to beg for alms in society [8]. These children, like their peers, are supposed to be in school studying, but they are utilized all day to assist their visually impaired relatives, parents, or grandparents, providing them with the essential care which is either

${ }^{2}$ Vision Loss Expert Group of the Global Burden of Disease Study. Trends in prevalence of blindness and distance and near vision impairment over 30 years: an analysis for the Global Burden of Disease Study. Lancet Global Health 2020. DOI: 10.1016/S2214-109X(20)30425-3. 
paid or not [9]. This has serious implications not only for the children future but also for Africa's as a whole. This is because the greater the number of children beggars, the higher the rate of child labour, child abuse, out-of-school- children, crime, and insecurity [10]. The widespread use of children as begging guides is partly why Sub-Saharan Africa has the highest rate of illiteracy and ignorant people. Today, the SubSaharan illiteracy rating stood at $34.7 \%$, the highest globally [11].

To address this problem, measures have been put in place to deter people with impairments from using children as begging guides. Public education of disabled people about the importance of educating their children, as well as vocational and technical training for people with disabilities, including visually impaired people, to learn about vocational jobs (such as weaving, shoe-making, soapmaking, and other important self-sustaining skilled activities) that can earn them money, are examples of such measures. Social and vocational rehabilitation training is available in countries such as Ghana [12, 13]. Ethiopia has a National Technical and Vocational Education and Training Strategy for Disabled People in its educational curriculum [14]. In South Africa, policies such as the strategic policy framework on disability for the postschool education and training system were put in place to provide technical skills and training to people with disabilities so they could make a living [15]. In Nigeria, social, medical, community, and academic rehabilitation and vocational training in areas such as cloth weaving, hairdressing, and carpentry were in place [16].

In addition, scientific research [17, 18] have been carried out to offer policy directions to end this ugly practice in Africa, yet the problem continued unchecked. Today, it is increasingly ravaging the fundamental human rights of children in countries like Tanzania, Nigeria, Zimbabwe, Ghana, South Africa, and other African countries. It has devastating effects on their mental stability. It denies them or limits their school attendance, thus making them highly illiterate and ignorant. Children are prone to abuse and rape, especially the female ones, who fall victim to sexual harassment and abuse by those they seek alms or help from. It is a national problem with social, economic, legal, political implications [19].

Africa, also share from the brunt in terms of large numbers of out-of-school children and, by extension, high crime rate and insecurity. For example, the rising rate of bandits, conflicts, and insurgency in the northern part of Nigeria has partly been attributed to large numbers of uneducated persons and out-of-school children, who are mainly the Almajiri children [21]. Most of the koranic schools in charge of these children seem to have lost control of them to persons with disabilities, who employ them as begging guides. This, in turn, has unduly exposed the children to social vices and extremists who also deploy them to fight against the Nigerian state [22].

Given the foregoing, this article argues that scientific research in this direction, which seeks to examine the rationale behind the use of children as begging guides, its effects on children and people with sensory disabilities, and mitigation strategies, will help to advance knowledge on the possibility of learning how to protect the fundamental human rights of the children engaged in it, in the designing of appropriate policy to address the problem of child begging in Africa.

\section{STATEMENT OF PROBLEM}

Children's use as begging guides for financial gain is child labour. It inflicts physical and psychological trauma on children [6]. This has remained a recurrent problem in parts of Africa, especially in Ghana [6], Tanzania [8], Nigeria [23]. Although governments in African countries where it is practised have instituted measures in forms of policy, law, arrest, and sanctions to discourage this practice among people with sensory disabilities, however, evidence shows that majority of these measures are only good on paper, they lack proper implementation and follow-up [6]. This breakdown has been unduly capitalized by people with sensory defects to engage in the use of children as begging guides in some African countries. Although studies have examined the consequences of begging among persons with disabilities or able-bodied persons as well as factors pushing or pulling them into it [24], evidence is very little about the rationale for the use of children as begging guides by their visually impaired parents and relatives. Besides, findings of previous studies have been more focused on the general consequences of begging, willingly perpetrated by children themselves; not much scientific research findings are in the public domain about begging, initiated or imposed on children by their visually impaired parents or relations. For instance, little attention is paid to the unwilling children, who were forced by their impaired parents. This gap is bridged by examining disability and children as begging guides. To address this broad aim, the article asks the question: 
for how long shall children be used as begging guides by visually impaired persons in Africa? This brings to the fore specific objectives of this study which include to:

i. examine the rationale (pulling and pushing factors) for the abusive use of children as begging guides;

ii. determine effects on children and people with sensory disabilities, and

iii. identify mitigation strategies against abusive use of children as begging guides in Africa.

Following the above sections, the article explains the theoretical foundation of disabilities and children as begging guides and the research methodology. This is followed by a presentation and analysis of findings before discussing results and then a conclusion.

\section{THEORETICAL UNDERPINNINGS}

\section{Social Exclusion and Childhood Theories}

The social exclusion theory specifically states that in any society, there are a certain group of people classified as misfits, and as such, they are not allowed or excluded from participating or enjoying basic incentives and utilities. The term 'exclusion' became very popular in 1960, as a social critique, in France. It was later used in 1974 to describe classes of people referred to as misfits consisting of both intellectually and physically disabled, single parents, bastards, drugs or substance abusers, anti-social behaved persons, and others not under any insurance cover [25]. This theory was adopted by the European council in 1984, and it defined the excluded as poor persons, families, groups whose resources are so small that they cannot fit the minimum acceptable standard of life of members of the state where they live [26]. This theory has been subjected to various discussions and criticism, especially among states that want to promote democratic principles, where all classes of people should be fully represented. Thus, this theory becomes very popular and handy, considering the inclusion of the marginalized in the development process of a country [8]. The point being made here is that in any society, there are categories of people classified as misfits based on their intellectual and physical disabilities, and as such, they are denied access to participate meaningfully in the development process of society. One such group is the group of physically disabled persons, who are excluded from job opportunities and other social benefits based on their physical or intellectual misfits.

This theory aptly described the fate of persons with sensory disabilities and children used as begging guides in Africa. In Africa, physically disabled persons, especially visually impaired persons, are a group of people [26], classified as misfits who are not accepted or does not meet the minimum standard of quality of life in their society. For example, in most African countries, persons with disabilities are excluded from job opportunities. Even when they manage to land a job, they are excluded and marginalized from the important decision-making process [27]. Similarly, children used as begging guides are excluded from attending school, thus denying them the right to education. Unlike their peers, these children are caregivers and what the theory describes as 'misfit' because they are poor and lack the resources required for their inclusion in the development process of their society. While children from wealthy and able-bodied parents are accepted and can contribute to the development process because they possess quality education, their counterparts from poor, disabled parents cannot adequately contribute to the development process of their society because they lack the knowledge. Specifically, it was revealed that children used as begging guides are socially excluded from education, healthcare, and leisure because their disabled parents or relatives are poor. They are prone to abuse, lack social respect, and suffer from the mental torture of not attending school due to their begging engagement [8].

The social exclusion theory, despite its wellelaborated explanation of the travails of disabled persons in terms of exclusion from the development process, fails to consider how knowledge and skills acquisitions programme can alleviate poor, disabled persons and caregivers from poverty, which in turn, enhances the inclusion in the development process. For example, not all disabled persons are poor and excluded from the decision making process. Evidence shows that some persons with sensory disabilities or caregivers have become very useful in society through vocational training [16]. Skills acquisition training like weaving, hair-plating, shoe-making, and others, have made some strong-willed disabled persons and their caregivers leave begging and contribute maximally to the development of their society [28]. However, this also depends on the good governance by the responsible government $[29,30]$. Adequate governmental intervention in the plight of disabled 
persons in African society will lessen their suffering and discourage them from abusively using their children as guides.

On the other hand, childhood theory defines 'childhood' as a socially constructed concept, which varies according to political context, the historical, socio-cultural and socio-economic context in which children's lives are situated [8]. Its principles are focused on children's right to education, health, protection against risks, threats, vulnerabilities, especially protection against street risks or harm. The theory was popularized by Locke (1632-1704) and Comenius (1592-1670). Good and normal childhood and bad and abnormal childhood [31]. The western idea of childhood, specifically on good childhood, has been made very popular and recognized globally through international development, debates on child rights and policies. This theory adequately applies to the plight of children being used as caregivers or begging guides by disabled persons, in that the childhood of these children or caregivers is akin to that of abnormal childhood described by Skovdal M. [31] because they lack access to education. For example, evidence shows that these children are highly vulnerable to street risks and harm [19-23]. As they guide their disabled parents, neighbours, or relatives on major highways for alms, they too are prone to risks of motor accidents, inter-group clashes, or the onslaught of armed robbery. In childhood, they lack good parental care, as they have assumed the role of a caregiver to their disabled parents or relatives [9]. Comparatively, children used as begging guides can be classified as those described by the childhood theory as abnormal childhood because they are denied access to attend school, healthcare, parental care, and also exposed to risks and abuses, unlike their peers from wealthy able-bodied parents or relatives. It is imperative to note that children used as begging guides are usually from poor socio-economic backgrounds and, most times, are pushed into such roles by their parents or relatives' poverty and physical conditions $[32,33]$. To address this beldam, there is a need to empower these children or youths to enable them to compete with their counterparts. This is consistent with the view that a youth empowerment programme is capable of alleviating children or youth from poverty [34].

THE IMPLICATION OF CHILDREN AS BEGGING GUIDES FOR INTELLECTUAL DISABILITY IN AFRICA

It is very obvious that the intellectual capacity of children used as beggars by their impaired parents cannot be the same as those who regularly attend classes and complete their assignments [18]. Children used as begging guides have low school attendance, and sometimes, they don't even have the opportunity to go to school. This invariably affects their academic performance, intelligence and contributes to their failure in examinations [6]. Similarly, children from this background suffer from the ability to relate and interact with their peers because of their low intelligence, which has been worsened or lessened by their begging business. This has a deeper implication for low intelligence for self-control against depression, isolation, and sometimes tendency of suicide among children. It was specifically revealed that many children with very low intellectual capacity and who have performed woefully in their academics had attempted suicide [35]. Relatedly, children beggars who have lost their right to education suffer from low intelligence to act soundly independent using their initiatives to solve the problem [35].

Furthermore, apart from the academic intellectual capacity of these children, their rational thinking mind is affected following their continual daily begging practice [36]. This is because the decision to be used as begging guides was forced on them by their impaired parents. This, in turn, has made many of them docile, irrational, and lose the astuteness and knowledge to act or think for themselves [18]. It has subjected many of these future African leaders to shame and lack of the intelligence to speak for themselves, they exhibit traits of intellectual weakness in almost what they are involved in, because they lack exposure and knowledge they could have acquired from school [8]. Across the globe, including Africa, children are potential leaders of the future. Their ability to cope and perform brilliantly and successfully in leadership positions depends on their intellectual ability, not disability. Begging children or those used as begging guides suffer from docility and low self-esteem due to their illogical thinking acumen [6]. It is difficult for a child who does not regularly attend a school or lacks access to education to display sound intellectual acumen and look mediocre [35].

One other implication of using children as begging guides in Africa is the inability of these children to intellectually forecast and predict what they would become in future and undertake actions in achieving their dream [8]. They are completely tied to the apron of guiding their impaired parents in the begging business and largely motivated by financial gains from the business than their personal human development 
[9]. Human development largely depends on intellectual capacity based on knowledge acquisition over time. Because of their parents' sensory disability, these children, directly and indirectly, suffer from poor knowledge, irrational behaviours (loneliness, docility, and ability to think and take proactive decisions that would benefit them [8].

At the household level, impaired parents also bear the brunt of their children's low or loss of intellectual capacity, which they use as begging guides. Although at the individual level, children suffer a great deal from the intellectual disability of not being able to compete academically with their peers or hold any position requiring sound knowledge or rational skills, the entire household, including the impaired parent, also suffer from the inability to draw from wealth and economic importance of their children [6]. In Africa, children are expected to adequately and conveniently represent their families or household as they grow old, especially in areas of knowledge, wisdom, maturity, and care for their parents [26]. To effectively take over from parents and act as a household leaders, children need to be intellectually sound, capable, and rational. It would be very difficult for children who have lived all their life as beggars and have mixed the opportunity to acquire knowledge and interact with educated people to manage their household, especially when they do not possess the intellectual ability.

Intellectual ability is a function of psychological stability, and evidence shows that children that are used as begging guides suffer from psychological stress partly due to fatigue of walking long miles and shame or embarrassment from seeing their peers going to school while they beg for money [6]. Most children love to do what their peers are doing; they feel dejected, unloved, and intellectually traumatized if they cannot act or play as their peers in society [36]. This, according to studies, has accounted for the growing trend of mental disability among children in Africa. Thus, any child who is mentally disabled can hardly do anything right, intellectually [37]. Mental retardation is one of the implications of children beggars in Africa. It retards their brain and contributes to intellectual disability, which is partly why few of them who eventually struggle to attend school find it very difficult to assimilate and comprehend their lessons.

In addition, mental retardation, poor academic performance, inability to hold leadership positions requiring rational thinking skills, docility, the exhibition of irrational behaviours, poor reasoning and low sense of predictions and forecast, child begging has a bigger implication for Africa's development, especially in the area of human capital development. From the available evidence, Africa has the highest numbers of child beggars and child labour in the world [37]. Relying on this report, it could be inferred that Africa may likely be hosting the largest number of children suffering from intellectual disability. This seems partly be correct, considering the low acquisition of knowledge and numbers of out-of-school children in Africa. Low acquisition of knowledge and out-of-school children are partly consequences of children's use as begging guides by sensory impaired parents in Africa [6].

The use of children as begging guides has adversely retard them intellectually in areas such as academics, reasoning and taking decisions by themselves, effectively replacing their old parents at the family or household level, leadership roles, social connections with peers, making meaningful contributions to societal development, advancing knowledge in human capital development and contributing to their own personal development. These not only affect the children but their families, society, and Africa as a whole.

\section{METHOD}

\section{Research Design}

This article adopts a qualitative research design, conducted from January to March 2021, at Agege, Lagos and Sabon-gari Kano, Nigeria. The choice of these research sites was based on the prevalence of children's use as begging guides by visually impaired Hausa parents. Agege and Sabon-gari were popularly known as Hausa dominated communities, where people with sensory disabilities, especially the visually impaired, used children as begging guides. This study was conducted in Nigeria purposively because there is no Nigerian state, including the country's capital, that is free from the ugly practice of using children as begging guides by sensory impaired persons. Similarly, the rationale for the qualitative method was based on suitability and the need for deeper reflection on the subject from participants, as visually impaired persons may find it very difficult to attend to questions on the questionnaire, as they hardly see with their sight. As conclusion and results from Nigeria can conveniently and fairly represent Africa, considering the huge population of people involved in the practice. 


\section{Participants and Data Collection}

Parents with sensory (impaired) disabilities, their children, who they used as begging guides, community health officers and teachers, as well as Serikis (leaders of the Islamic community), form the participants of this study. The study involved three parents, five children, one community health officer, one teacher and one Seriki purposively selected in each of the states. The ages of these children ranged between 8 and 14 years. The article only used data from purposively selected Serikis, parents, community health officers and teachers, and children. One from each group of Seriki, community health officer and teacher from Hausa communities in Agege and Sabon-gari, were selected to get background opinion on the reasons why most visually impaired Hausa parents prefer using their children as begging guides and as expatiating on the links between Islam and begging, as well as consequences of begging on health and education. All the five parents' participants were illiterates from the Hausa tribe, and all of them had children, who they have regularly been using as begging guides. One of the three children in each research site was a gatekeeper who assisted with community access and familiarization with potential participants. He was highly instrumental in informing the Seriki and parents about the motive of the research. Key Informants Interviews was the method adopted to get the parents' opinion about the use of children as begging guides.

The essence of this method is that information from key informants are usually correct and factual, especially when they are directly involved in the practice. Parents with sensory (impaired) disabilities are directly involved in the use of children as begging guides. There was a high-level consideration for the cultural values of research participants as some of them are women operating under the Islamic purdah system. Given this, two Muslim female research assistants who can fluently speak the Hausa language were employed to conduct the KIls with females' parents and children. The rationale for this decision was based on the understanding that female parents and children would likely be more open to providing indepth opinions about interview questions to the female researcher than the authors, who are all males. Questions such as 'what is the rationale for your begging? Why do you use your children as a begging guide? How do you feel using them as a begging guide? What are the effects on your children and you? How do you feel seeing your friends going to school? Why do you think your parents use you as a begging guide?' were part of the interview questions asked parents and children. The in-depth semi-structured interview was used to collect data from community health officers, teachers and Seriki in each community. They were asked questions on the importance of education, the effects of begging on children health and education, their role in addressing the issue and likely mitigation strategies. This interview method produces comprehensive accounts of the subject from the interviewees' perspective [38].

Participants' observation was also used to get a comprehensive picture of the issue under study, as research assistants are residents of the area, they observed when parents and their children go for begging, engaged in informal conversations with the children to identify possible threats and abuses on these children, this, complement the formal data collection. Field notes were used to document observations on the research site. Responses from all the participants were recorded using audio-tape, and they granted permission before the data were transcribed, translated and analyzed. The pseudonym was used during the transcription of data to protect the identities of the participants. Data were analyzed using thematic content analysis. It is the use of coding by generating themes in line with the research objectives and analyzing the content of responses gathered from participants in relation to each research objective. Codes were in the form of numbers $(1,2,3$ etc.) identification in each category of participants. For instance, parent-1, child-1, Seriki-1, respectively.

\section{RESULTS}

Results were presented and analyzed using themes that cover the objectives. The first objective examines the rationale for the use of children as begging guides by people with sensory disabilities.

\section{The Rationale for the Use of Children as Begging Guides}

This objective aims to advance new knowledge on causes, including pushing and pulling factors that stimulate the forceful use of children by visually impaired parents. As earlier noted, codes were used to protect participants' identities and make them feel very comfortable to answer questions such as: Why are you using your children as begging guides? Why does your parent use you as a begging guide? Why do their impaired parents use children to beg for money? All these questions apply to all participants; while the first two apply to sensory impaired parents and their 
children, the other applies to community teachers, health officers, and Seriki. All participants identified poverty as one of the causes of the use of children as begging guides.

Lack of help and poverty to feed my family made me force my children to lead me while I beg. If I don't do that, how do we feed? Since I have a loss of my sight, it is very difficult to feed ${ }^{3}$.

The above submission from one of the sensory impaired parents was consistent with others. The response of one of the begging children was particularly more revealing. He has this to say:

Initially, I refused my mother's force to be used as a begging lead, but when the suffering at home was too much, I was joined by other younger brothers who have been doing it. We have no money and helper to feed us. It is now our means of livelihood. Without it, we cannot eat ${ }^{4}$.

A critical look at the submission by the child above indicates the use of force by parents on their children. By their narration, poverty is certainly one of the rationales why most parents with impaired vision forcefully use their children as begging guides. This could have been borne out of the need to feed the children and partly due to discrimination they suffer in society, which is why some of them preferred using their children as begging guides. For instance, for the community teacher:

Most of these visually impaired people use their children as a last resort, to beg for money when it seems everyone, including the government, has abandoned them, and it is also because the majority of parents involved in it are ignorant and uneducated ${ }^{5}$.

It is also clear that apart from poverty, discrimination in forms of exclusion of visually impaired people from access to basic essential services as well as ignorance and their poor level of education pushed them to settle for the use of their children as begging guides. This also could have been possible, especially among impaired parents who may have tried to reach out to families and friends in terms of assistance but get

\footnotetext{
${ }^{3}$ Interview with parent-1.

${ }^{4}$ Interview with Child-3.

${ }^{5}$ Interview with Community teacher-2.
}

nothing from several attempts, and this could have forced them into the idea of using their children as begging guides. In addition to this, one of the participants in the parents' category identified the need to survive. She specifically submits that:

Life was not the same when I lost my
sight; the thought of how my children will
survive came to my mind. I am not
thinking of myself because I am old, but
how do my children cope, feed, and
survive? This led me to use my last child
as a begging guide while others attended
school. This has been the means of
survival in this family ${ }^{6}$.

Although this looks very similar to poverty, it also contributes to why some visually impaired parents use their children as begging guides.

You know Islam requires us to give to the poor, and because of this reason, many visually impaired people who are Muslims use the opportunity to beg for money, and the people willingly give to them to fulfil the command of Allah ${ }^{7}$.

From the foregoing submission, religion seems to be one of the reasons parents, especially, Muslims' cling to the use of their children as begging guides in some African societies. This is highly consistent with the view of the second Seriki in the Sabon-gari community, Kano. He specifically notes that:

Zakatul- Fitr is a doctrine in the Quran that
requires us to give to the poor who have
gone out to beg to have something to eat
and be happy. Based on this,
handicapped Muslims, including those
with sight problems, have resorted to
begging, believing it is the right thing to
do. In fact, people give them money during
worship, intending to receive blessings
from God ${ }^{8}$.

This narration points to the fact that religion is a strong rationale for the use of children as begging guides. This aptly supports that of the community health officer in the Hausa community in Lagos. Her submission lay credence to the fact that it is not only common among Muslims but other religions too.

\footnotetext{
${ }^{6}$ Interview with parent-3.

Interview with Seriki-1.

${ }^{8}$ Interview with Seriki-2.
} 
In this community, visually impaired persons who are Christian also use their children as beggars, and they rely on the doctrine of the rich and poor man parable in the bible, where Jesus Christ admonished his disciples to give to the poor among them. You know handicapped people are poor because of their disability. They hardly fend for themselves; this pushes them to start begging in society, understanding that they would get help from people ${ }^{9}$.

Whether Islam or Christianity, religion is a strong rationale that influences both the receiver and giver of alms. And this can be interpreted to mean that African society also contributes to begging. People who give alms or money are from society. Although it can be argued that they are doing that under the influence of religion, it can be convincingly interpreted to mean that society supports begging in Africa. Other reasons attributed to child beggars include poor governmental intervention, control, policy, laziness, economic hardships, and greed or financial gain.

In this area, there is the complete absence of control or sanction from the government against the use of children as begging guides, and this has pulled many of them, both the genuine impaired persons and fake ones, into the business ${ }^{10}$.

This shows that financial gain or profiteering is another rationale for using children as begging guides. From the above result, it is obvious that some people perpetrate this act with their children for financial purposes due to a lack of checks and control on their activity by the government.

A critical analysis of findings on the first objective shows that the factors such as poverty, religion, absence of government control and sanctions, economic hardships, survival needs, financial gain, society, breakdown in the implementation of policy on disability, greed, among others are the rationale for children beggars in Africa.

\section{The Effects of Children as Begging Guides on Children and Parents}

This theme is a reflection of the second objective of this study, which examines the implications of the ugly

\footnotetext{
${ }^{9}$ Interview with community health officer-2

${ }^{10}$ Interview with community teacher- 1.
}

act of begging on children and parents with impaired vision. This objective advances understanding of the travails and pains of these children and their visually impaired parents.

It makes me ashamed and cries inside me without any help, and I cry because if I don't do it, I will not eat, and my father cannot but his drugs ${ }^{11}$.

In addition to this finding, the one from child-5 was particularly more touching and revealing.

I only attend school once a week, and sometimes, when we don't generate enough money, I don't go to school throughout that week. I feel bad to see my friends go to school while I begged for money; it makes me weak and unloved ${ }^{12}$.

Narrations above indicate sorrow, shame, poor school attendance, psychological trauma, silent weeping as effects of begging on children.

As a teacher in this community, it is very rare to see them perform brilliantly in their academics; they are always back seaters in the class because of late coming, and they perform woefully academically, which affects their education generally ${ }^{13}$.

This is similar to what was obtained from other participants, especially from parents and the community health officer. For one of the parents:

Although I cannot see my daughter's face because of my blind sight, I know she feels bad seeing her friends walk to school while she is leading me to beg in the neighbourhood. This normally occurs early morning and afternoon, during school hours; I have pleaded with her to understand, but as a child, she cannot control her emotions, and I feel bad too ${ }^{14}$.

It also affects their health, as they suffer from long trekking under the scorching sun. This increases the body temperature and blood pressure of their parents. They are easily prone to contagious diseases and infections because they openly beg in public places like

\footnotetext{
${ }^{11}$ Interview with Child-1.

${ }^{12}$ Interview with Child-5.

${ }^{13}$ Interview with community teacher-2.

${ }^{14}$ Interview with parent-2.
} 
markets and churches where large numbers of people converge ${ }^{15}$.

It is obvious from submissions above that children's access to education, good health, and parental care are denied by their conscription into the begging initiative of their parents. The parents, too, are affected as the long trek while begging increases their blood pressure, exposing them to heart complications and other related diseases. The two Serikis' took a departure from others as they revealed that both children and parents involved in begging, especially female children and parents, are susceptible to sexual abuse, harassment, and in a severe situation, rape ${ }^{16}$. In confirmation of this finding, one of the impaired parents narrated her ordeal with thugs in Lagos. She specifically confirmed an attempted rape on her and her children during one of their begging outings along the railway at Pen Cinema, Agege ${ }^{17}$.

As a parent, I suffer silently from the guilt of not being able to provide parental care for my children due to my predicament and their deliberate use as begging guides, and it made me feel very low in the spirit, knowing that I contribute to their poor academic performance ${ }^{18}$.

Other participants (teacher, health officer, and Seriki) provided information on deeper implications of this type of begging. For instance, the response of the teacher-1 covered societal implications such as an increase in numbers of out-school-children, idleness and their involvement in crimes that threaten the peace and security of the community; affected children may continue with begging even after the demise of their parents $^{19}$.

Reactions in view of this objective showed that children involved in the business of begging guide suffer from psychological trauma, sexual abuse, violence, poor academic performance in school, if at all they attend, health complications, stress, and low selfesteem, especially among their peers. And for the parent with impaired vision and who uses their children, they silently grieved over their inability to provide parental care for their children, and they suffer from health problems such as hypertension, body weakness, and easily prone to infectious diseases.

\footnotetext{
${ }^{15}$ Interview with community health officer-1.

${ }^{16}$ Interviews with Seriki-1 and 2.

${ }^{17}$ Interviews with parent-3.

${ }^{18}$ Interview with parent-2.

${ }^{19}$ Interview with teacher-1.
}

\section{Mitigation Strategies Against the Use of Children as Begging Guides}

To address these inherent challenges, all participants called for sincere interventions from the government, non-governmental organizations, and religious bodies to rescue the visually impaired persons. They were also of the view that members of society should be orientated to avoid stigmatizing people with disabilities and report any discrimination against them, especially in areas of job opportunity, access to basic amenities, and other public utilities.

The solution to this problem could also come from proper engagement of parents with impaired vision about the importance of their children; once they understand this, it could reduce the abusive use of their children as begging guides ${ }^{20}$.

This narration points to the fact that ensuring that parents who perpetrate this act understand the importance of education is one of the strategies that would lessen children's use as begging guides.

In the past, the government used to monitor and arrest beggars, especially children, but there are no more sanctions and arrests today. To stop this problem, the government should re-introduce $i t^{21}$.

Re-introduction of policies and sanctions against children beggars and sending parents are also parts of solutions to the problem. To buttress other participants' views on this, one of the participants' suggestions in the children category was particularly a strong resolution to the problem. For her:

The empowerment of my father and other visually impaired parents in vocational skills and knowledge could reduce child begging. My father has no vocational skills, apart from being a security guard before his blindness. We see some blind people earn money from weaving, sewing, making of other essentials through vocational skills ${ }^{22}$.

It is evidenced from this submission that empowerment of visually impaired persons is one of

\footnotetext{
${ }^{20}$ Interview with teacher-1.

${ }^{21}$ Interview with Seriki-1.

${ }^{22}$ Interview with child-1.
} 
the available strategies that can be deployed to reduce the problem of children begging.

\section{DISCUSSION}

In exploring visually impaired disabilities and children as begging guides in Africa, the section discusses three salient issues that emerged from our findings. Firstly, there were unanimous opinions on the rationale for the children as begging guides. Secondly, the practice of child begging has severe implications for the children, parents, and Africa. Thirdly, the role of government in some Africa countries, especially, Nigeria related to the issue of child begging, is absent.

On the rationale for children as begging guides in Africa, results from the literature show that poverty among disabled, blind persons makes them use their children as begging guides because feeding these children also depends on the amount generated. Evidence shows that in Ghana, Kenya, South Africa and Nigeria, poverty has been widely alluded to as the cause of children's use as begging guides [39-42]. For example, how do children of poor blind parents feed, especially when their relatives have abandoned them, and the government is not forthcoming in terms of safeguarding their interests? Both results from the field and literature convincingly confirmed that poverty is a strong rationale for child begging in Africa.

Furthermore, lack of and poor recognition of the importance of education by parents with impaired vision are among the causes of children's use as begging guides in some African societies. Many of these groups are highly uneducated partly because their sight has been impaired since birth or ignorance, and so they may not fully understand why their children should be educated. This belief or thinking is common among impaired parents from the Hausa-Fulani ethnic group in Nigeria [23], Dodoma in Tanzania [8], and Beitbridge/Messina border in Zimbabwe [43], Dagbon in Ghana [6].

Religious, cultural, and contemporary economic influences have also been blamed for begging persons with disabilities [43]. On religious influence, the necessity of materials and religious morality drive people with impaired vision and their children to beg on the one hand and motivate the givers to give alms to them on the other hand [43]. In Islam (Zakatul- Fitr) and Christianity (the parable of the rich and poor Lazarus), popular doctrines require people to give alms to the poor, including people with disabilities. This has made religious gatherings in churches and mosques important markets for beggars. For givers, giving to the poor, as stipulated by these doctrines, could make them achieve eternal life. This is another religious dimension unduly exploited by some visually impaired persons in Africa.

Economic and political hardships and meltdown pushed many disabled persons into begging in Africa. For example, the economic hardship in Zimbabwe pushes lots of handicapped and visually impaired into migration for begging business in South Africa [43].

Moreover, the deliberate action of parents to use their children as begging guides could also be caused by greediness, to draw pity or sympathy, and the urge to make fast money. Despite all interventions and empowerment initiatives to protect persons with disabilities and prevent them from begging, some of them, out of greediness, still continue in the business [8]. The laws in South Africa does not support begging, yet the practice continues to thrive [43]. These beggars and their assistants or children strongly showcase their disability through songs, prayers to givers or passersby to draw sympathetic feelings towards their deplorable condition. The use of children as begging guides draws feelings of pity and sympathy to beggars [8].

On implications of this problem to children, parents, and Africa, results showed social, political, economic and legal implications. Socio-economic implications include; first, children suffer from the loss of or denial of the right to education [6]. This is because they hardly go to school, and even if they attend, their performance is woeful [8]. Their poor performance is attributed to absenteeism and lateness to classes [6]. It is very difficult to combine begging assistant duty with education at an early age. Those who tried it have either dropped out of school or become truant [8]. Children who rotate between school and begging duties have always suffered from poor performance in school.

Besides, it implies subjecting children to mental trauma and shamefulness. Naturally, begging in public places, especially when one is able and fit, could sometimes be shameful because people see such a person as poor and incapacitated [44]. Relatedly, children could develop mental trauma when they see their mates going to school [6]. Children, especially those in primary schools, are easily moved by peer influence and pressure. Thus, seeing their peers go to school while guiding their blind parents could be made them feel unhappy and mentally upset. 
Exposure to abuse and harassment of all sorts are inevitable for children used as begging guides [8]. The risk of rape and sexual harassment is high, especially among young girls' while boys are subjected to insults and taunts, which tend to abuse their personality as human beings.

It also hampers the general well-being of the children, as they are prone to diseases and other contagious ailments in public places [43]. It also affects the healthcare and general well-being of the children, especially those whose livelihood depends on their begging blind parents or relatives [43]. For instance, since begging is an all-daylong activity, these children work and move tirelessly from one location to the other in search of who will give them alms. They sometimes walk long distances and, on several occasions, they have been mistakenly hit by vehicles, sustaining injuries that affect their general well-being.

Their parents who use them for begging suffer from regrets of their inability to provide good parental care for their children. They are also silently saddened from the pain of deliberately denying their children the chance to attend school and access education and healthcare services [6]. Just like their children, parents too suffer from sexual harassment and rape, and they are suffering from discrimination, exclusion, and isolation by families and relatives [6].

For Africa, the achievement of the SDG four (education for all) suffers from timely accomplishment by 2030 [5]. Also, Africa's ranking as the continent with the highest number of out-of-school children could be partly due to the recurrent use of children as begging guides [44]. This has contributed to the rising trends of crimes and insecurity in parts of Africa, especially Nigeria [34]. This is due to the breakdown in implementing policies and prompt follow-up on sanctions against child begging in some African countries [6]. This is not to say that there are no laws against begging, but implementing these laws has repeatedly been problematic in some African countries.

Lastly, in addition to socio-economic and political implications, it has legal implications in those established laws prohibiting begging have been violated by people with sensory disabilities in most African countries, especially at the community level. However, ignorant and low level of education of most impaired persons engaged in begging, coupled with poor enforcement by the government, these laws have continually been violated unpunished in most African society. Similarly, the fundamental human rights of children used as begging guides have been abused by their parents. This has severe implications in the face of law as it can attract severe punishment.

\section{CONCLUSION AND RECOMMENDATIONS}

The use of children as begging guides has no value for children and society as a whole. It has done more harm to children, their blind parents, and society. Although the use of children as begging guides is multifaceted, none of these reasons is justifiable and edifying considering its effects on society, disabled persons, and young children. African countries and the entire continent are not safe from endangering the future of young children in a bid to care for people with sensory disabilities. For how long shall the practice continue? The suggestions in subsequent paragraphs became necessary in addressing this question.

The orientation of the uneducated or ignorant, blind beggars is a good step in the right direction to achieve an end in using youngsters as begging guides in Africa. Informing them about the importance of their children education, as the way out from poverty, will lessen the abuse of children by their parents for begging. It will also safeguard the children right to education, thus reducing the number of out-of-school children in Africa.

Government should be more forthcoming and proactive in protecting persons with disabilities, especially in areas of laws and assistance, training, empowerment, special job opportunities preferences for disabled persons, among others. Once this aspect of their need is handled, the tendency of using their children to beg for alms, all things being equal, would be reduced.

Furthermore, there is a need to promulgate laws against begging in Africa. It is a fact that some African countries (South Africa, Kenya, Zimbabwe, and few others) have laws in place against begging, yet, it still continues unabated [43]. The problem is partly poor implementation; with prompt enforcement of laws, the use of children as beggars will probably be a thing of the past in Africa [45].

Society needs to understand that begging is a bad practice that should not be condoned. It thrives and continues because members of society are in support of it. And since society is made up of people, there is a need to educate them to eschew the attitude of clinging to cultural sentiments in supports of beggars. They 
should be exposed to the fact while sympathy for beggars is good, it should not be used as an object of weakness or laziness to encourage them. People should be cautioned to place more emphasis on the knowledge power of beggars as human beings than their physical weakness or disability. This will go a long way in discouraging begging and shifting the focus to human or capacity development.

Religious leaders, during sermons, should ensure a balance between doctrines of giving and dignity in labour. This will provide adequate balanced information to worshippers on how to determine, when and who to give alms as the case may be. Religious morals should be clearly defined and explained to worshippers to promote dignity, hardworking, and equality.

\section{FUTURE RESEARCH}

There is a need to have a rethink this ravaging practice if Africa is to achieve SDG four (quality education for all). The incidence of out-of-school children arising from the use of children as begging guides requires urgent attention of scientific research in examining the implications of child begging for out-ofschool children in Africa.

Similarly, this study has exposed the need for scientific research to interrogate the cause and implications of breakdown in laws, policies, and sanctions prohibiting child begging in Africa. This is important because research in this direction will go a long way in discouraging children's use as beggars in Africa.

More importantly, this study exposes the need for future scientific investigation to examine the connection between child begging, crimes, and insecurity in Africa. It is important to understand if the increasing rate of crimes and insecurity in Africa is connected to children beggars.

\section{LIMITATIONS}

Apart from female research assistants, authors were not allowed into the two communities for the interview. This prevented adequate observation of the communities and participants' family settings with sensory disabilities and their children. But many detailed interviews were conducted by the female research assistants. Besides, there was an initial refusal from the head of beggars' association in those communities to grant the interview, but after an adequate explanation of the motive of the research, the interview was grudgingly allowed to take place. This created some fear in participants as some questions were deliberately avoided.

\section{ETHICS}

Permission was sought from the closest local government authority to the two communities before the research was conducted. Ethical clearance was obtained from relevant institutions in each state. Participants were informed of the motive of the study, and the consent forms were translated into the Hausa language, and it was read to all participants before they signed to participate in the study. They were informed about keeping their identity confidential and made to understand that pseudonyms have been used in place of their names and community for the purpose of anonymity. They were also assured that they could withdraw from the study at any time they wished. An appropriate time that is convenient for all the participants was chosen so that all could be available for the interview.

\section{REFERENCES}

[1] Abebe $\mathrm{Y}$, Malle RP, Timo $\mathrm{S}$. Inclusion of students with disabilities in formal vocational education programs in Ethiopia. International Journal of Special Education 2015; 30(2): 57-67.

[2] McKinney V. An exploratory case study on the preparation of undergraduate civil engineering students at the University of Cape Town to contribute to an inclusive society for people disabilities. Unpublished $\mathrm{PhD}$ thesis, University of Cape Town 2016.

[3] Tobias El, Mukhopadhyay S. Disability and social exclusion: Experiences of individuals with visual impairments in the Oshikoto and Oshana Regions of Namibia. Psychology and Developing Societies 2017; 29(1): 22-43. https://doi.org/10.1177/0971333616689203

[4] Mace SE. Global threats to child safety. Pediatric Clinics of North America 2016; 63(1): 19-35. https://doi.org/10.1016/j.pcl.2015.09.003

[5] UNICEF. Childhood under threat: The state of the world's children 2005. Childhood under threat: The state of the world's children. New York: UNICEF 2005.

[6] Fuseini T, Daniel M. Child begging, as a manifestation of child labour in Dagbon of Northern Ghana, the perspectives of mallams and parents. Children and Youth Services Review 2020; 4(1): 1-14. https://doi.org/10.1016/j.childyouth.2020.104836

[7] Vision Loss Expert Group of the Global Burden of Disease Study. Trends in prevalence of blindness and distance and near vision impairment over 30 years: an analysis for the Global Burden of Disease Study. The Lancet Global Health 2021; 9(2): E130-E143. https://doi.org/10.1016/S2214-109X(20)30425-3

[8] Abdallah JS. Causes and effects of begging style involving children as guides in Dodoma municipality, Tanzania: Liability in basic education access. International Journal of Education and Literacy Studies 2017; 5(1): 1-12. https://doi.org/10.7575/aiac.ijels.v.5n.1p.1 
[9] Seni AJ. The experiences and perceptions encountered by young carers of visually impaired adult beggars in Tanzania: Implications for access to basic education. European Journal of Education Studies 2016; 2(1): 1-15.

[10] Lance L, Enrico M. The effect of education on crime: evidence from prison inmates, arrests, and self-reports. The American Economic Review, (Cambridge, MA) Working 2004; Paper No. 8605.

[11] Szmigiera M. The illiteracy rate among all adults (over 15year-old) in 2019, by world region. Statista, 2021. Available from https://www.statista.com/statistics/262886/illiteracyrates-by-world-regions/

[12] Gyamfi N, Mprah WK, Edusei AK, Dogbe JA, Owusu I. Relevance of vocational training programme for persons with disabilities in the Ashanti Region of Ghana. Journal of Disability 2015; 1(2): 69-76.

[13] Fuseini T, Daniel M. Exploring the stressors and resources of Muslim child beggars in Dagbon of Northern Ghana in the context of child rights and existing realities. Children and Youth Services Review 2018; 111(1): 1-10. https://doi.org/10.1080/23311886.2018.1542955

[14] Ministry of Education. National technical and vocational education and training TVET strategy. Addis Ababa: Brihaneselam Printing Press 2008.

[15] Department of Higher Education and Training. Strategic policy framework on disability for the post-school education and training system, 2008. Available from https://www.dhet.gov.za/SiteAssets/Gazettes/Approved\%20S trategic\%20Disability\%20Policy\%20Framework\%20Layout22 0518.pdf

[16] Omede AA, Okpe JE. Vocational rehabilitation programmes for disabled people in Nigeria: Problems and prospects. International Journal of Economics, Commerce and Management 2016; 4(6): 846-852.

[17] Magashi SB. Education and the right to development of the child in northern Nigeria: A proposal for reforming the Almajiri institution. Africa Today 2015; 61(3): 64-83. https://doi.org/10.2979/africatoday.61.3.65

[18] Ahmed BK, Abdul Razak KA. Caring for blind parents: cost to the education and well-being of children in Tamale, Ghanian. Journal of Social Work in Disability and Rehabilitation 2016; 15(1): 22-41. https://doi.org/10.1080/1536710X.2016.1124252

[19] Esobonu OS. An influence of socio-economic status of parents on children development. Journal of Sociology 2012; 4(2): $64-80$

[20] Usoro P. Critique and comment understanding and responding to begging. Australian Journal 2007; 1(1): 1-16.

[21] Akali O. The Almajiri in Northern Nigeria: Militancy, perceptions, challenges and state policies. African Conflict and Peacebuilding Review 2015; 5(2): 128-142. https://doi.org/10.2979/africonfpeacrevi.5.2.128

[22] Aghedo I, Eke SJ. From Alms to Arms: The Almajiri Phenomenon and Internal Security in Northern Nigeria. The Korean Journal of Policy Studies 2013; 28(3): 97-123. https://doi.org/10.52372/kjps28305

[23] Bukoye RO. Case study: Prevalence and consequences of streets begging among adults and children in Nigeria, Suleja Metropolis. Social and Behavioral Sciences 2015; 171(1): 323-333.

https://doi.org/10.1016/j.sbspro.2015.01.129

[24] Namwata BML, Mgabo MR, Dimoso P. Feelings of beggars on begging life and their survival livelihoods in urban areas of Central Tanzania. International Journal of Physical and Social Sciences 2012; 2(7): 1-12.

[25] Ryan L, Sales R, Tilki M, Siara B. Social networks, social support, and social capital: The experiences of recent polish migrants in London. Sociology 2008; (42)4: 672-690. https://doi.org/10.1177/0038038508091622
[26] Holland J. Young people and social capital: Uses and abuses? Young 2009; 17(4): 331-350.

https://doi.org/10.1177/110330880901700401

[27] Uromi SM, Mazagwa MI. Challenges facing people with disabilities and possible solutions in Tanzania. Journal of Educational Policy and Entrepreneurial Research 2014; 1(2): 158-165.

[28] Correll L, Correll T. The Tanzanian National Costed Plan of Action for most vulnerable children: A human capacity needs assessment: Dar es Salaam: USAID, 2006. Available from https://www.socialserviceworkforce.org/system/ files/resource/files/The_Tanzania_National_Plan_of_Action_f or_Most_Vulnerable_Children_1. pdf

[29] Agunyai SC. Emerging Governance Crises in Twenty-First Century Nigeria. In: Adebusuyi A, Ikuteijo K, Eds. Africa now: Emerging issues and alternative perspective. United Kingdom: Palgrave Macmillan Press 2018; pp. 211-239. https://doi.org/10.1007/978-3-319-62443-3 10

[30] Agunyai SC, Olawoyin KW. Legislative-executive corruption and good governance in Nigeria: Insights from Buhari's administration in the fourth republic. In: Omololu $F$, Fayth $R$, Eds. Perspectives on the legislature of accountability in Nigeria and South Africa. Switzerland: Springer International Publishing AG 2019; pp. 105-119. https://doi.org/10.1007/978-3-319-93509-6 6

[31] Skovdal M. Young carers in Western Kenya: Collective struggles and coping strategies. [Doctoral thesis, London School of Economics and Political Science] 2009 CORE. https://core.ac.uk/display/4187453

[32] Adelowo O. Almajiri: As Niger moves to tackle problem. The Nigerian Tribune, March 17 2010; pp. 15 https://scholar.google.com/scholar?q=Adelowo, $\% 200 . \% 20$, \%20Almajiri:\%20As\%20Niger\%20Moves $\% 20$ to\%20Tackle $\%$ 20Problem. \%20The\%20Nigerian\%20Tribune,\%20March\%20 17\%202010\%20Pg.\%2015.

[33] Balogun A. New forms of begging on Lagos Street. The punch Newspaper, 17th March, 2012; pp. 18 https://www.nairaland.com/895644/new-forms-begginglagos-streets

[34] Badejo BT, Agunyai SC, Adeyemi OO. Policy, youth recruitment and empowerment in Nigeria: A case study of Osun state youth empowerment scheme (OYES). Mediterranean Journal of Social Sciences 2015; 6(1): 384393. https://doi.org/10.5901/mjss.2015.v6n1s1p384

[35] Erica L, Elizabeth DB, Rachel G, Maryland P, Jeffrey B, William $R$, Lisa $H$. Suicide risk in youth with intellectual disability: The challenges of screening. Journal of Development and Behavioral Pediatric 2012; 33(5): 431-440. https://doi.org/10.1097/DBP.0b013e3182599295

[36] Tassé MJ, Aman MG, Hammer D, Rojahn J. The Nisonger Child Behavior Rating Form: Age and gender effects and norms. Research in Developmental Disabilities 1996; 17(1): 59-75. https://doi.org/10.1016/0891-4222(95)00037-2

[37] Rush KS, Bowman LG, Eidman SL, Toole LM, Mortenson BP. Assessing psychopathology in individuals with developmental disabilities. Behavior Modification 2004; 28(5): 621-637. https://doi.org/10.1177/0145445503259830

[38] Green J, Thorogood N. Qualitative methods for health research. 3rd ed. Los Angeles: Sage 2014.

[39] Boaten AB. An examination on the phenomenon of street children in selected communities in Accra (Ghana), A dissertation presented to the faculty of the college of education of Ohio University in partial fulfillment of the requirements for the degree Doctor of Philosophy. Ohio: Ohio University Press 2006. 
[40] Suda C. Street children in Nairobi and the African cultural ideology of kin-based support system: Change and challenge. Child Abuse Review 1997; 6(3): 199-217.

https://doi.org/10.1002/(SICl)10990852(199708)6:3<199::AID-CAR306>3.0.CO;2-D

[41] Malindi MJ, Machenjedze N. The role of school engagement in strengthening resilience among male street children. South African Journal of Psychology 2012; 42(1): 71-81. https://doi.org/10.1177/008124631204200108

[42] Catherine LW, John RS. South African street children: A survey and recommendations for services. Development Southern Africa 2010; 27(1): 85-100. https://doi.org/10.1080/03768350903519374

[43] Katsande R. Begging for a title: An ethnographic research report on Zimbabwean blind beggars. Masters Dissertation
Report 2012. Available from https://wiredspace.wits.ac.za/bitstream/handle/10539/15382/ Blind\%20beggars\%20Masters\%20Research\%20Thesis $\% 20$ by $\% 20$ Rukariro\%20Katsande $\% 20$ w.pdf?sequence $=2$

[44] Van Acker J, Oostrom B, Rath B, De Kemp, R. Street children in Nairobi: Hakuna Matata? Journal of Community Psychology 1999; 27: 393-404.

[45] Becker S, Evans R. Hidden young carers: The experiences, needs and resilience of children caring for parents and relatives with HIVIAIDS in tanzania and the United Kingdom. Stakeholder Report, School of Sociology and Social Policy University of Nottingham, UK 2007. Available from: http://doc.ukdataservice.ac.uk/doc/6002/mrdoc/pdf/6002ugui de.pdf

Received on 01-09-2021

https://doi.org/10.6000/2292-2598.2021.09.06.4

(C) 2021 Agunyai and Ojakorotu; Licensee Lifescience Global.

This is an open access article licensed under the terms of the Creative Commons Attribution License (http://creativecommons.org/licenses/by/4.0/) which permits unrestricted use, distribution and reproduction in any medium, provided the work is properly cited. 